\title{
Why do Canadians use so much plasma?
}

A s controversy swirls around the planned launch of three paid plasma donation clinics in Toronto and Hamilton, Ontario, no one seems to be asking why Canada needs so much plasma in the first place.

Canada is among the top three highest users of intravenous immunoglobulin (IVIG) per capita in the world. IVIG - derived from the plasma of hundreds of diseases, including immunodeficiency, and hematologic and neurologic disorders.

For the past few years, Canada has been trading the top-user spot with the United States and Australia, according to Adrienne Silver, manager of communications at Canadian Blood Services. The latest 2012 data from the Marketing Research Bureau puts Canada slightly behind the US and Australia, at 146.4 kilograms per million people, but ahead of 20 other countries surveyed, including the United Kingdom, Germany and Switzerland, where usage ranged from 53.5 to 74.6 kilograms, respectively.

According to the Canadian Blood Services 2012/13 annual report, immune globulin ate up about $\$ 202$ million - a quarter of the organization's expenses - and the high cost raises questions about whether it's being used appropriately. thousands of donors - is used to treat

Although immunodeficiency diseases can be treated only with immune globulin, other blood and neurologic disorders can often be treated with either drugs or IVIG. The drugs cost the patient money, but plasma protein products are provided free of charge by provincial health ministries, which buy them from Canadian Blood Services and its Quebec counterpart, Héma-Québec.

Dr. David Anderson, clinical advisor of the Nova Scotia Provincial Blood Coordination Program points out that many in the Canadian medical community are concerned decisions to prescribe IVIG might be based more on the zero cost to the patient than efficacy.

"The blood products are dealt with in a totally different way than the drugs, from a financial perspective," he says. "That isn't necessarily in the best interest of patient care or the most costeffective manner of delivering care from a societal perspective."

Dr. Graham Sher, CEO of Canadian Blood Services, says that the use of plasma protein therapies has been rapidly expanded to new conditions in the past two decades, sometimes based on anecdotal evidence. "There may not be randomized controlled trials to show benefit in a lot of cases," he says.

The demand for IVIG in Canada has grown by an average of $6 \%-8 \%$ each

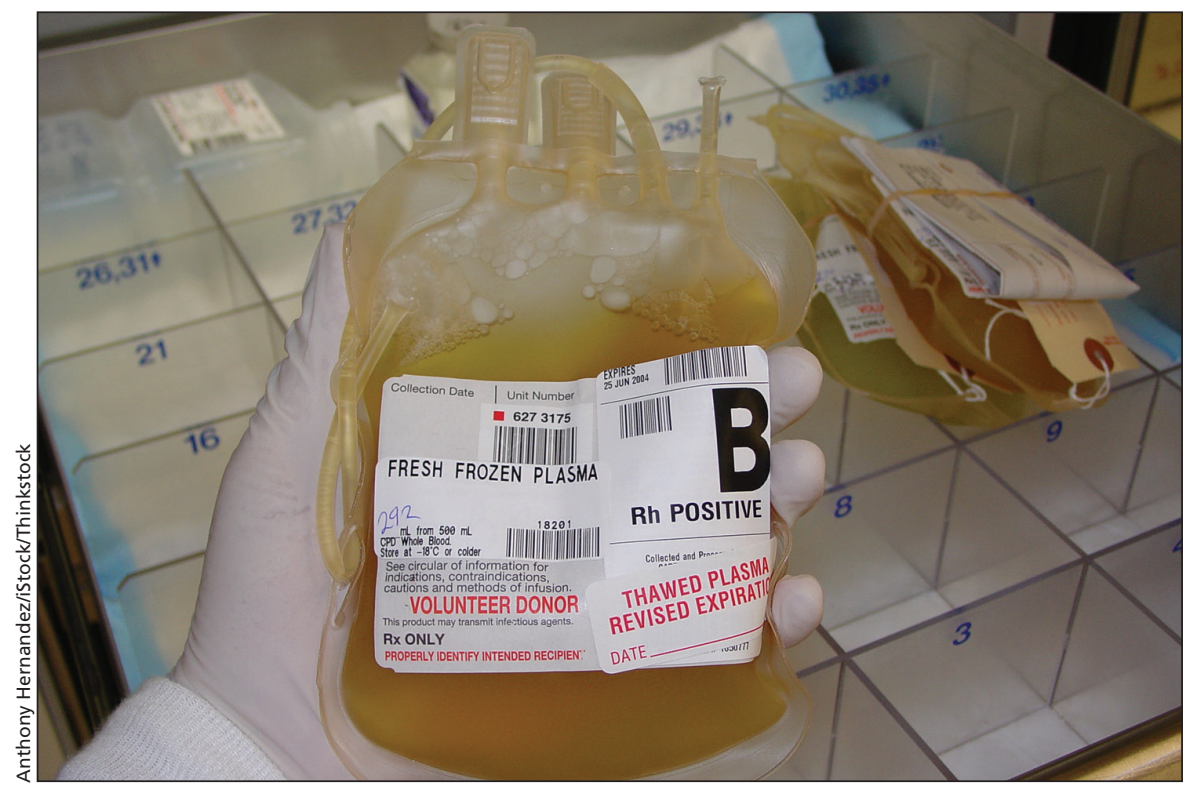

Many in the Canadian medical community are concerned that decisions to prescribe IVIG might be driven by its zero cost to the patient rather than its efficacy. year for the last decade, according to data from Canadian Blood Services.

But because there hasn't been a cost-benefit analysis comparing the treatment of rare diseases with plasma proteins versus other drugs, "we don't know if Canada's higher use of immune globulin is good or bad," says Dr. Jean De Serres, president and CEO of HémaQuébec.

On the positive side, $30 \%$ of immune globulin is used to treat primary immune deficiency disorders, for which it is the only treatment. "We know what we're treating everyone who is diagnosed with this disease in Canada, which is not the case in other countries," says De Serres.

Richard Thompson, CEO of immunodeficiency Canada, says the diagnosis of primary immune deficiency is better here in part because of the medical education provided by his organization, but $70 \%$ of patients living with the disease still go without a diagnosis.

British Columbia, Ontario and the Atlantic provinces have implemented guidelines and approval systems to try to ensure appropriate IVIG usage. In 2012, the Atlantic provinces began requiring physicians to state the indication for which they prescribe IVIG and to obtain approval. In situations where the indication doesn't meet evidencebased guidelines, the responsible blood transfusion physician at the laboratory would question the doctor, and clinical experts could be called upon to review contentious requests, Anderson says. Ontario launched an IVIG request form, which was widely adopted in 2012, while BC has been screening all requests for IVIG at the hospital level (and sometimes at the provincial level) for more than a decade.

Meanwhile, Héma-Québec is working to increase its immune globulin supply from $15 \%$ to $30 \%$ of the amount used in Québec through in-province voluntary donations. "The goal is to have enough in case of a catastrophe like war," says De Serres. "It's good to have some self-sufficiency in any country." - Wendy Glauser, Toronto, Ont.

CMAJ 2014. DOI:10.1503/cmaj.109-4862 